\title{
THE IMPACT OF EXPERTS ON TAX POLICY IN POST-WAR BRITAIN AND SWEDEN
}

\author{
Per F. ANDERSSON
}

During the decades after World War II, countries began shifting taxation from income to consumption. This shift has been associated with an expanding welfare state and left-wing dominance. However, the pattern is far from uniform and while some left-wing governments indeed expanded consumption taxation, others did not. This paper seeks to explain why, by exploring how experts influenced post-war tax policy in Britain and Sweden. Experts influence is crucial when explaining how the left began to see consumption tax not as a threat but as an opportunity. Interestingly, the influence of experts such as Nicholas Kaldor in Britain was different from the impact of Swedish experts (e.g. Gösta Rehn). I make the argument that the impact of expert advice is contingent on the political risks facing governments. The low risks facing the Swedish Left made it more amenable to the advantages of broad-based sales taxes, while the high-risk environment in Britain made Labour reject these ideas.

Keywords: taxation, expert influence, economic history, political economy

JEL classification indices: H20, H23, H61, N44

Per F. Andersson, Doctoral student at the Department of Political Science, Lund University, Sweden. E-mail: per.andersson@svet.lu.se 


\section{INTRODUCTION}

Parties to the Left have traditionally favoured progressive taxes on income and wealth over regressive taxes on consumption. ${ }^{1}$ However, during the decades following World War II, this attitude changed, and countries with a strong Left became associated with a heavy reliance on consumption taxes (e.g. Steinmo 1993; Kato 2003). How did this change come about? And why did some left-wing governments expand consumption taxation early, while others lagged behind? In a detailed comparative case study of left-wing tax policies in Britain and Sweden, I show that individual economic experts were essential in changing ideas concerning taxation and its impact on equality. Though key experts in Britain and Sweden - Nicholas Kaldor and Gösta Rehn in particular - presented similar ideas and had similar access to key decision-makers, their impact was very different. In Sweden, Rehn's arguments in favour of consumption taxes eventually convinced the Social Democrats, and a broad-based sales tax was introduced in 1959. Meanwhile in Britain, Kaldor's advocacy in favour of the value-added tax (VAT) was rejected, and Labour (at a later point) instead adopted his proposal for a Selective Employment Tax (in essence a tax on labour in the service sector).

In order to explain the link between ideology and taxation, we need to understand the impact of experts. Following Lindvall (2009), I argue that experts had an impact on the set of tools the Left had at its disposal, but not on the goals of economic policy. In practice, this meant changing the dominant view that the path to equality was through the taxation of income and capital. By highlighting the effect of consumption taxes on evasion and tax revenues, in conjunction with the possibility to offset its regressive effects by spending (or changes in other taxes), experts provided a new way for the Left to fight inequality.

However, the presence of experts and their ideas cannot explain the ultimate choice made by governments. Why was the idea of an expansion of consumption taxation successful in Sweden while it failed in Britain? I argue that the choice crucially depends on the political risks involved in introducing regressive taxes. Labour in Britain was concerned that the instruments initially suggested by Kaldor (e.g. a VAT) would be incompatible with their goals in the long run, and thus rejected the idea. In Sweden, on the other hand, the Social Democrats, facing a different political environment, were more amenable to broad-based consumption taxes as instruments for economic equality. Thus, the impact of expert ideas depends on the strategic situation facing the Left.

1 Taxes on consumption have been shown to have a regressive impact, while income taxes are generally progressive (see, for example, Joumard et al. 2012; Prasad - Deng 2009). 
There is a wealth of research on the impact of ideology on economic policy. While early contributions found that left-wing rule is associated with lower unemployment, larger governments, and more welfare spending (Cusack 1997; Hibbs 1977; Cameron 1978; Hicks -Swank 1992; Kittel - Obinger 2003), a recent meta-analysis of 43 studies found no consistent impact of ideology on economic policy (Imbeau et al. 2001). Lately, attention has shifted to the counter-intuitive positive relationship between left-wing dominance and regressive taxation of consumption (Kato 2003; Ganghof 2006; Cusack - Beramendi 2006; Beramendi - Rueda 2007). These later contributions share the view that the Left ideally seeks to tax progressively, but is constrained by corporatism, constitutions, or increased spending pressure coupled with the threat of the exit of capital. A related argument is that the Left taxes its own voters primarily for compliance reasons (Timmons 2010). In contrast to these studies, I show that the Left sometimes introduces broad-based consumption taxes not because it is constrained, but because it genuinely believes that it contributes to the party's overall goal.

While much earlier research into the politics of indirect taxation ignores the role of experts, there are exceptions (such as Martin 2015). However, even though Martin acknowledges that experts had a role in the development of indirect taxation in Denmark, the main explanatory variable remains the patterns of social partnership, not the impact of experts. Moreover, she is mainly concerned with the influence of employers' organisations and right-wing parties, while the puzzle this paper explores is why left-wing governments tax consumption.

Hicks (2013) emphasises the strength of the Left when explaining health care policy and relates this to the degree of the unification of the opposition. In a similar vein, Andersson (2016) highlights the importance of opposition influence in explaining tax policy, and stresses how this is partly a function of formal political institutions. While these two arguments are helpful in understanding the institutional constraints facing the Left, they cannot explain how the ideas regarding consumption taxes evolved. Moreover, fundamental changes in tax policy cannot be explained by invoking institutional factors alone. In order to understand the change in left-wing attitudes towards consumption taxation, we need to investigate the influence of individual economic experts since the new ideas about consumption taxation and redistribution did not solely come from within the parties themselves.

The next section describes the empirical strategy and introduces the two cases. After that, I investigate the impact of economic experts on post-war tax policy in Britain and Sweden, with special attention to consumption taxation. The final sections elaborate on why the impact of experts was different in Britain and Sweden, and what general conclusions can be drawn about the conditional impact of experts on tax policy. 


\section{EMPIRICAL STRATEGY AND CASE SELECTION}

Britain and Sweden are interesting cases to compare because they not only share a number of formal institutional features, but also faced similar conditions and challenges after World War II, with experts presenting similar solutions. Interestingly, the choice of solution differed, with Sweden opting for a broad-based sales tax and Britain for a tax on employees in the service sector.

Both Britain and Sweden are unitary constitutional monarchies, and since Britain was victorious and Sweden neutral during World War II, there was political continuity and the Left did not come to power as a result of a radical reshaping of the political system. After the war, both countries were ruled by strong left-wing governments and both parties advocated for heavier taxation of the rich as a way to fight economic inequality and were firmly opposed to consumption taxes (SAP election manifesto 1944; Dale 2000: 49f).

The two countries also faced similar challenges concerning the general economic situation and taxation. As a result of wartime spending, taxes in Britain and Sweden needed to be brought back to peacetime levels. How this was done reflected the political considerations at the time: in Britain, changes in the income tax were mainly aimed at the middle-income working class voters, while in Sweden, the temporary sales tax introduced during the war was removed. ${ }^{2}$

A common problem in both countries was that the income tax not only affected an increasingly larger portion of the working class (as a result of inflation and the war), it was also increasingly avoided by the rich who could more easily shift between wage and capital income. These factors challenged the prevailing orthodoxy that a tax system based on income tax was always preferred from a distributional standpoint.

A contextual factor salient in both countries was inflation, which was used by Labour to motivate increases in a number of excises (whose regressive effect to some degree was compensated for by raised food subsidies). Similarly, the initial response to inflation in Sweden was to use excises, but also the interest rate.

The main focus of the case studies is economic experts, their ideas, and their access to key decision-makers. The political party/coalition making up the government is a key actor since it is effectively setting tax policy. Although the focus is on Left-parties, the preferences of parties to the right are also important, as they affect the risk assessment of the Left. Attention will also be paid to trade unions

2 Britain had a so-called purchase tax, but this was mainly on luxury goods and with differentiated rates. Thus, it was a consumption tax, but with decidedly progressive elements. While keeping the tax after the war, in 1948 Labour decided not to broaden the base of the tax since it was "not politically defensible" (Whiting 2000: 91). 
and employers' organisations since, as earlier research has argued, they are crucial in explaining tax policy change (see, e.g., Beramendi - Rueda 2007; Martin 2015). However, it is important to bear in mind that the parliament sets tax policy, not unions (Bradley et al. 2003).

\section{BRITISH POST-WAR TAX POLICY AND THE INFLUENCE OF NICHOLAS KALDOR}

As a general principle, preferring income to consumption tax worked well in the pre-Second World War era when most Labour voters did not reach the income required to pay the tax. But when Clement Attlee was appointed Prime Minister in 1946 the situation had changed. Income tax now reached also the working class and as part of returning Britain to peace time tax levels, the standard rate of income tax was reduced from 50 to 45 percent (Thorpe 2008: 123). The failure to introduce a tax on capital gains and/or wealth during Attlee's prime ministership was cited later as the main contributor to rising inequality, and it shaped the tax debate within Labour during the following years in opposition.

\section{Debating indirect taxation in opposition}

Despite being rewarded in the polls, Labour lost the 1951 election (Thorpe 2008: 140). ${ }^{3}$ The new Churchill government shifted economic policy in a generally regressive direction by abolishing food subsidies and lowering income tax rates. Although the Tories did introduce a short-run capital gains tax, its main purpose was to fight avoidance, not to reduce inequality (Whiting 2000: 155). No major changes to the tax systems were implemented and tax policy was used more for appeasing unions than for providing incentives (Daunton 2002: 264).

Labour spent these years in opposition re-evaluating its tax policies. As mentioned above, avoidance among top income earners had undermined the progressivity of the income tax and alternative methods of taxation were discussed (Whiting 2000: 152). An important development was that the impact of taxation on efficiency and revenue gained more attention. Labour MP Anthony Crosland stated in 1962 that what he called "socialist" taxes "should therefore enable us to

3 The election resulted in the largest vote share in Labour history, $48.8 \%$, but the $13,948,883$ votes brought only 295 seats, while the Conservatives' $48 \%$ of the votes produced 321 . These dramatic results caused by the electoral system were not uncommon in Britain, and is an important difference between the British and Swedish political system (Heclo 2010: 37). 
consider $[\ldots]$ certain elastic and high yielding indirect taxes - a general turnover tax, a differential payroll tax, or a graduated and much higher employers' national insurance contribution. ... For what matters is the total progressiveness of the tax system - and, if we want to redress its total imbalance, its total yield" (quoted in Whiting 2000: 151).

One of the more innovative suggestions came from the Cambridge economist (and member of the 1956 Royal Commission on the Taxation of Profits and Income) Nicholas Kaldor, who suggested a tax based on spending. Instead of using income as a tax base, which punished savings, Kaldor suggested using an individual's spending power, which also included wealth and irregular income (Kaldor 1955). ${ }^{4}$ While economists in the party supported the proposed tax, it was rejected because of its expected unpopularity and departure from the orthodox view that strongly favoured the income tax (Whiting 2000: 137).

During these years, Hugh Gaitskell, shadow Chancellor from 1951 until 1955 (when he became Leader of the Opposition), realised that increasing redistribution through the income tax alone was no longer possible, but instead turned his attention towards property as the main culprit of inequality (Ellison 2002: 86). A proposed capital levy was considered unviable in terms of public opinion and the prevailing position in the later 1950s was in support for a capital gains tax, a tax on gifts, and taxation of unearned incomes (ibid. 87f).

In sum, debate and deliberation within the party during the opposition years prepared Labour for reforms when they returned to power after winning the 1964 general election. Several new instruments such as the expenditure tax were presented, but while versions of broad-based consumption taxes were discussed, momentum shifted in favour of taxes on capital because of the regressive effects of the former. After winning the election, Labour employed Nicholas Kaldor as special adviser to the Chancellor on taxation, which proved to be of great importance for future Labour tax policy (NK/10/1/2 1964).

\section{Back in power: the 1965 budget}

The first budget under Prime Minister Harold Wilson (who took office in 1964) was not only concerned with raising revenue and minimising avoidance, but also with making the tax system fairer. ${ }^{5}$ The budget reformed and simplified the cor-

4 Kaldor also suggested what he called "the expenditure tax" in his minority report to the Royal Commission on the Taxation of Profits and Income 1956.

5 The budget was fiercely debated and took twice the time in parliament than normal (Whiting 2000: 160). 
poration tax, but the changes did not have a noticeable impact on inequality and were revenue neutral. It also introduced a comprehensive capital gains tax (both long and short run) as compensation for union wage restraint (Daunton 2002: 292), but due to business pressure, the rate was set to 30 per cent, which was lower than the income tax rate (Whiting 2000: 163).

Critics within the party were concerned that the focus on avoidance would create an excessively intrusive tax administration and that the budget would disproportionately hurt small business. As an alternative, they suggested a broad-based consumption tax and a lower income tax. The Labour leadership was aware of the deficiencies in the income tax, but instead of introducing a new tax on consumption, they decided to strengthen the legitimacy of the income tax by making it more progressive and by increasing efforts to combat avoidance (ibid. 167).

In the years following the budget, the consensus was that the tax administration needed time to catch up before new tax reforms could be implemented. During this time, the value-added tax (VAT) re-emerged on the agenda (ibid. 171). For example, the Confederation of British Industry (CBI) criticised the extent of government expenditures and the level of direct taxes, and recommended lower expenditures overall and a shift from direct to indirect taxation (ibid. 193).

During the same time, the first empirical investigations on the incidence of indirect taxes emerged, showing how hard the poor were hit by existing excise and consumption taxes. Poverty was no longer simply an issue of class, and reducing inequality increasingly meant spending more on the poor. This increased tensions within Labour between representing the unions and reducing inequality, and slowed down Labour's efforts to redistribute from the middle to the poor (Whiting 2000: 173ff). Despite these tensions, inequality was reduced and the situation of the poor improved (ibid. 181-183).

\section{An unorthodox alternative to the VAT}

When the National Economic Development Council (NEDC) suggested a VAT back in 1963, Labour rejected it with reference to its adverse effects on inequality (Daunton 2002: 289). But when it was discussed again in 1965, it was mainly as a solution to Britain's balance of payment problem (CAB/129/121 1965). Since Labour did not want to devalue the pound sterling, other measures - such as changing elements of the tax system - were considered. A VAT was proposed as a way of offering export incentives without violating the rules of the General Agreement on Tariffs and Trade (GATT). But critics soon pointed out that the existing purchase tax did not fall on exports, so replacing it with a VAT would not be an improvement in this regard. 
Since the effect of a VAT on exports was unclear, two other advantages were emphasised. First, by the mid-1960s, it was generally believed that Labour could not raise income taxes more without serious electoral backlash (Whiting 2000:197) and Labour had explicitly ruled out any increases in the income tax in a public statement before the 1966 election (Thirlwall 1987: 242). A VAT would allow Labour to extract more revenue at less political cost. Second, expanding the existing purchase tax (at that time covering only selected goods) would result in a political fight over every added good; introducing a VAT covering virtually all goods and services (which were not covered by the purchase tax) would be far easier politically (Daunton 2002: 294).

Notwithstanding its advantages, many within Labour viewed VAT as politically dangerous because of its regressive effects. Nicholas Kaldor - at this time a VAT supporter - proposed a solution: by replacing social contributions (essentially a regressive flat-rate poll tax) with a VAT, the regressive impact would be mitigated. Kaldor also pointed out that the VAT would raise considerable revenue with less distortion of production and consumption. His proposal was met with heavy resistance from the Treasury, the Board of Trade, and the Department of Economic Affairs. The most serious objection was that contributions fell on labour, while the VAT would also hurt groups outside of the labour force such as married women and pensioners. Moreover, Customs and Excise were concerned about the administrative costs associated with the new tax (Daunton 2002: 295f).

Regardless of these objections, the problems of weak exports and increasing revenue needs were still urgent. At this point, Kaldor presented an alternative that promised to solve these problems without resorting to the dreaded VAT: the Selective Employment Tax (SET). The tax was paid by the employer based on the number of employees, with tax rebates to the manufacturing sector. The SET would encourage reallocation of labour from the service sector to manufacturing, as well as raise revenues (which would partly be used to subsidise exports) (Whiting 2000: 198). Most importantly, it would be more politically palatable than a VAT (Daunton 2002: 297f). Labour preferred this solution to the introduction of a broad-based, regressive consumption tax and introduced the SET already in 1966.

While Labour Chancellor Callaghan was pleased with this solution, the Trade Union Confederation (TUC) was not. It expressed concern about the equity effects of the SET and with the overall progressivity of the tax system. But although the SET was not the best solution, ${ }^{6}$ the TUC preferred it to a broad-based VAT (NK 11/17/8-12 1970). The CBI and the Tories on the other hand preferred a

6 The TUC preferred a progressive Selective Payroll Tax (SPT), a tax that - it was argued would retain the beneficial effects of the SET, but with a less regressive profile. 
VAT (Rollings 2003: 235; Lynch 2003: 59), especially in combination with Britain joining the European Economic Community (EEC).

The VAT question was intimately tied to the EEC since membership required the harmonisation of several taxes. In connection with Britain's second application to the EEC, a Committee (of which Kaldor was a member, as was fellow Hungarian-British economist Thomas Balogh) was set up to investigate the impact of introducing a VAT. ${ }^{7}$ Despite the expectations of Prime Minister Wilson, the report recommended not to introduce the VAT - even though it acknowledged that a VAT would solve the revenue problem - for three reasons: (1) Britain did not have the problem with cascading turnover taxes that made other European countries positive toward the tax; (2) introducing the VAT would mean significantly higher administrative costs; and (3) a VAT would not enhance industrial efficiency the way the SET did (328/100 1967). In something of an anticlimax, the second application was also vetoed by de Gaulle (in 1967) and the report was never even discussed in the committee (Whiting 2000: 204). Thus, it is hard to judge the policy impact of this report and, by extension, the advice of Kaldor as a member.

\section{Conclusion}

Post-war tax politics in Britain was characterised by the crisis of the existing tax system and the struggle to find new solutions to inequality, funding needs, and industrial efficiency. Among the economic experts providing advice and ideas, Nicholas Kaldor stands out, first as an academic and later as special adviser. Advising the Wilson ministry, he presented several ideas of how taxation could solve problems related to the balance of payments and revenue needs. However, his initial propositions regarding consumption taxation were rejected with reference to the distributive impact. Labour resistance towards broad-based consumption taxes was related to political risk and this led Kaldor to present alternative solutions. Labour accepted the SET since it was more acceptable politically, while solving similar problems as a VAT. While Kaldor did not influence the goals of Labour policy, he did provide a number of alternatives to reach them. When Labour rejected one alternative because it was too risky (the VAT), Kaldor quickly provided a safer alternative (the SET). This suggests that the influence of expert ideas is not unconditional, but depends on the political situation facing the government.

The first application was submitted by the Macmillan ministry and vetoed by Charles de Gaulle in 1963. 


\section{EXPANDING CONSUMPTION TAXATION IN SWEDEN}

During the World War II, all parties in the Swedish parliament (the Riksdag), except for the pro-Soviet Communists, were represented in government. The Social Democratic Party (SAP) was victorious in the 1944 election, but the wartime government remained in office until the end of the war. When SAP Prime Minister Per Albin Hansson died in 1946, he was succeeded by Tage Erlander, who went on to lead the country for the next twenty-three years. ${ }^{8}$

After the war, all political parties agreed that Sweden should return to peacetime taxation, which meant removing the temporary sales tax and lowering the income tax. The SAP tax policies were heavily influenced by - and debated with two prominent economists from the Swedish Trade Union Confederation (LO): Gösta Rehn and Rudolf Meidner.

\section{The sales tax is abolished (and mourned)}

The SAP had always been hostile towards indirect taxes, which were seen as regressive and unfair. The 1944 party program (in effect until 1960) called for redistribution and progressive taxation, in particular on wealth and income. In an economic environment with stable prices and high brackets for the income tax, shifting taxation from indirect to direct meant that better-off citizens paid more. However, as in the British case, inflation led to bracket creep, pushing more and more working class voters into the income tax. As if this was not enough, tax evasion at the top was rampant, with the well-off having little trouble transforming their income from wage to capital. This prompted the party to re-evaluate its stance on indirect and direct taxation, and made it open to new ideas.

The temporary broad-based sales tax (the "oms") ${ }^{9}$ was introduced to meet the sharply increased defence spending during the war and was abolished in 1947. Interestingly, the SAP finance minister overseeing the removal of the oms - Ernst Wigforss - later described the abolition of the tax as a mistake driven by political necessity. It was not possible to lower a progressive tax like the income tax and at

8 Of course, this was not something the SAP knew at the time. In fact, the risk of losing power was always present and the party could only form a majority government once (in 1968).

9 "oms" is short for "omsättningsskatt", literally "turnover tax". A tax referred to as "försäljningsskatt" was introduced in 1948, but although the literal translation is "sales tax" this tax concerned only a few goods: precious metals, pearls, certain carpets, and gramophone records and related equipment (1952 års kommitté för indirekta skatter 1957:.60). I employ the commonly used translation "sales tax" for "omsättningsskatt" (see for example Steinmo (1993:126) or simply "oms" when referring to this tax. 
the same time keep a regressive consumption tax, especially not since SAP had a very narrow majority in the parliament (Wigforss 1954: 336ff.).

But it was not only actors within the ruling left-wing party that mourned the demise of the oms: as early as 1946, Gösta Rehn and Rudolf Meidner - prominent LO economists - started to argue in favour of indirect taxes on consumption (e.g. Rehn 1946). This was followed by similar articles in the SAP magazine Tiden (1948) and in the LO outlet Fackföreningsrörelsen (1946). Rehn, together with future Governor of the central bank, Per Åsbrink, claimed that removing the oms had been a mistake and that judging indirect taxes only on its incidence and not what the revenue is used for was like throwing the baby out with the bathwater (Åsbrink - Rehn 1951). Although taxes on consumption hurt the poor, if the revenues were spent disproportionally on these groups, there should be no quarrel with the tax on distributional grounds. Moreover, taxation of consumption had two additional advantages. First, it was harder to avoid than the increasingly avoided income tax. Second, in a time of rising prices and full employment, consumption tax was seen as a formidable tool for balancing the economy. Conscious about the political difficulties of such a reform, Rehn cited a recent poll where respondents were asked whether they preferred removing the oms or keeping the oms if it financed certain social policies. Among the working class, 39\% wanted to keep the oms, while 51\% wanted it abolished (Rehn 1946), suggesting that the electoral risks associated with the oms were exaggerated.

Experts also influenced the debate through two public inquires, one into direct (1951) and another concerning indirect (1957) taxation. The report issued in 1951, which was the result of the committee on direct taxation commissioned in 1949, is interesting for several reasons. First, the report - supposedly focusing only on direct taxation - spends considerable amount of ink on the balance between indirect and direct taxation, sparking a serious debate on the issue. Second, the report allowed Gösta Rehn, an official member of the commission, to fully express his views on the matter (which had not changed since his earlier writings) ${ }^{10}$ Both unions and business peak organisations agreed with the main points of the report, although they differed in their preferred level of total taxation (Konseljakt (Cabinet meeting) 31 mars 1952).

Despite the recommendations in the 1951 report - and the support from the unions and industry associations - no major changes were made to indirect taxation during the following years. The priority was fighting inflation and instead of using a re-introduced sales tax to do this, the government chose excises and increased interest rates.

10 However, since his opinion diverged from that of the LO, he could not use his own name. The dissenting opinion of E. Åkerström is in fact the opinion of Rehn (Elvander 1972). 
During this period, Rehn and Meidner met repeatedly with Prime Minister Erlander and other ministers discussing the issue of indirect taxation. In 1955, Meidner suggested a re-introduction of the oms, but representatives from the government were hesitant, and the Finance Minister (Per Edvin Sköld) was outright hostile to the idea (Erlander 1976: 265). Erlander writes that although the ideas of Rehn and Meidner later became central to SAP economic policy, they were politically impossible to implement at the time (Erlander 1974: 235f, 1976: 39). Rehn continued his advocacy not only in meetings and internal memos to the SAP, but also - as mentioned above - in the labour movement press.

\section{The return of the "oms"}

The reintroduction of the general sales tax was preceded by the second major tax inquiry of the decade, published in 1957: the 1952 Committee on Indirect Taxation (of which Rudolf Meidner was a member). The report concluded that indirect taxation had several advantages over direct taxation. First, indirect taxes had lower administrative costs, especially compared with the rates of current direct taxes. Second, a move to indirect taxes on consumption would reduce tax evasion and have a positive effect on work incentives and savings. Third, consumption taxes would provide a more effective and flexible tool for fighting inflation. The report recommended that the new consumption tax should be broad-based with uniform rates (although some goods could be excluded for special reasons). Importantly, the committee acknowledged the fact that these types of taxes hit some groups - such as families and pensioners - especially hard, and recommended compensating these groups using government spending rather than providing exemptions or lower rates for certain goods (1952 års kommittée för indirekta skatter 1957). ${ }^{11}$ The report formed the basis for the later decision in the parliament.

Although the LO agreed with some of the proposed advantages with indirect taxation, such as lower evasion and its possible use in fighting inflation, it advised against the tax. The main reason was the fear that compensation through government transfers might be a temporary arrangement, while the tax would be permanent. Surprisingly, even though the LO was opposed to this particular tax, it states that a VAT could be plausible in the future as a replacement for the tax on profits (Konseljakt (Cabinet meeting) 9 oktober 1959: 21).

11 The report was careful to leave the issue of whether the tax should be introduced or not up to the parliament. 
The Federation of Swedish Industries recommended an immediate introduction of a general consumption tax if it meant maintained or lower overall tax levels, but strongly advised against the tax as a way of expanding government (ibid.).

\section{The decision}

The SAP government was finally convinced by the arguments in support of a broad-based sales tax, and claiming the LO opposition was weakening, Erlander decided to go through with the reintroduction of the oms in 1959.

Surprisingly to the SAP (minority) government, none of the right-wing parties supported a reintroduction of the oms. This meant they had to rely on the Communists to push through the bill (Erlander 1976: 267ff). ${ }^{12}$

In the parliamentary debates, the Conservatives (Högerpartiet), the Liberals (Folkpartiet), the Farmer's League (Bondeförbundet) as well as the Communists were strongly opposed to a reintroduction of the sales tax, albeit for very different reasons. The Right - primarily the liberals and the conservatives - feared that a return of the sales tax would increase the size of government. For the Communists, the sales tax represented a regressive tax hurting the poorest workers the most, and thus unacceptable (Andra Kammarens Protokoll [minutes of the second chamber] 1959).

The reintroduction of the oms lead to a significant increase of revenues from consumption taxes, less dependence on the income tax, as well as sharply increased social spending (Andersson - Brambor 2015; Flora et al. 1983). According to a poll made prior to the 1960 general election (in 1959), most SAP voters opposed the oms, but after the election, a majority supported the tax. Särlvik (1967) presents data suggesting this was an effect of SAP appealing to attitudes toward welfare expenditure and party loyalty during the election campaign. SAP also gained three seats in the election (Nohlen - Stöver 2010: 1872), indicating that the strategy paid off. That is, it seems Rehn was right in that compensatory spending could help sell the oms.

\section{Conclusion}

Through publications in labour outlets, government reports, and personal meetings with key ministers, economic experts such as Rehn and Meidner influenced the instruments available to the Social Democratic government. As in the British

12 The Communist Party had the choice between accepting the oms or in effect terminating the SAP government. It chose the former. 
case, the experts did not affect the ultimate goals of policy, but they did affect the instruments available to reach them.

Interestingly, in 1959 the SAP stance was more in line with the opinion of business peak organisations and economic experts than with the LO ${ }^{13}$ Moreover, the right-wing parties in parliament also opposed the tax.

As Steinmo (1993, ch. 5) has pointed out, an important factor in Swedish politics during this era was the SAP majority in the upper chamber. However, probably more important is the fact that there was no unified strong opposition at the time (see also Hicks 2013). The Social Democrats had been in coalition with the Farmer's League from 1951 to 1957 and, more often than not, the Right disagreed among themselves on economic policy. This, coupled with SAP being the largest party in parliament, meant it could reasonably expect to have influence over policy in the future - even when not in government - and this extended its time horizon and lowered the risks associated with consumption taxation.

\section{HOW ECONOMIC EXPERTS MATTER}

In both countries, the Left traditionally considered income tax to be the prime tool to reduce economic inequalities. But the situation after the war - with income taxes affecting the working class, while the rich could increasingly avoid it - made policy makers in both Britain and Sweden amenable to new ideas. Economic experts in Britain (primarily Nicholas Kaldor) and Sweden (mainly Gösta Rehn and Rudolf Meidner) argued that a broad-based consumption tax would be harder to avoid, have less harmful effects on the economy, and generate considerable revenues. Conscious about the ultimate goal of left-wing governments, the experts were careful in emphasising how the regressive impact of the tax could be counteracted (through replacement of contributions in Britain or increased transfers in Sweden).

Kaldor, Rehn, and Meidner were all members of important committees on taxation, where they were able to shape the policy debate. ${ }^{14}$ They also had access to key decision-makers: Kaldor as special adviser on taxation and Rehn and Meidner in their repeated meetings with Erlander and key ministers. An important

13 In its opinion on the 1959 report, LO acknowledges that compensation might work, but judges the political problems too hard to overcome. Curiously, in the same document, the LO comes out in favour of a VAT, suggesting that the technical implementation of the sales tax was the issue, not the general shift towards consumption taxation.

14 Although Kaldor's most influential role was as co-author of the minority report to the main 1956 report (where he proposed the expenditure tax) and Rehn had to use another name to be able to fully express his views in the 1951 report. 
difference is that while both Rehn and Meidner were affiliated with LO, Kaldor came from academia. As Lindvall (2009) notes, experts provided instruments to reach a certain goal, but did not affect the goal itself.

Although the experts provided similar ideas concerning consumption taxation - in particular the advantages of a broad-based consumption tax - these were adopted by the SAP, but not by Labour. Why was the SAP government more amenable to this type of expert advice than Labour? A key factor seems to have been the long-term effects of changes to the tax system. Labour, facing a more uncertain future if losing an election (since the incoming government would be a strong Conservative majority government), preferred a tax policy that did not cement regressive elements. This concern was also the main explanation for TUC resistance. Thus, choosing Kaldor's less dangerous alternative - the SET - over the highly contentious VAT made sense given the political context.

The role of the future in shaping the risks associated with tax reforms is related to the literature on policy insulation. Building on the work by de Figueiredo (2002), Hicks (2013) argues that in the case of health care policy, Labour strategically locked in redistributive elements in order to constrain future Conservative governments, while Sweden opted for a system prioritising administrative efficiency. The reason for this difference, he argues, is that the Left was weak in Britain and thus needed to use the opportunity while in power to tie the hands of future governments. The reluctance of Labour to "lock in" regressive elements in the tax code through a VAT can be seen as a case of this more general behaviour of trying to tie the hands of your successor. In the 1967 report on the VAT, the flexibility and freedom associated with the existing system of indirect taxation was cited as a main advantage over the VAT, which if introduced would constrain efforts to mitigate the regressive impact of consumption taxes by, for example, exempting certain goods (PRO T 328/100 1967). In essence, Labour wanted to lock in policies that reduced inequality (such as their health care system), but not regressive policies such as the VAT.

Hicks links the strength of the left to the type of opposition they were facing: a strong unified Right in Britain, and a divided Right in Sweden. In a similar argument, Andersson (2016) relates expectations of the future to formal political institutions, leading the Left in Sweden to expect more influence as an opposition party than in Britain. ${ }^{15}$ This arguably lowered the political risk associated with the reintroduction

15 Of the 17 British elections between 1920 and 1980, 14 resulted in single party majorities, but only in two cases did the winning party secure a majority of the popular vote (Butler - Butler 2010). In contrast, in the 19 Swedish elections between 1920 and 1980, there was only one single-party majority government (after the 1968 election). The period is otherwise dominated by single-party minority governments and coalitions (Hadenius 2003). 
of the oms in Sweden. In sum, there are several factors making the risks of losing power greater for the Left in Britain than in Sweden and, by extension, the risks associated with consumption taxes. Thus, the impact of experts on left-wing taxation is not uniform but depends on the political environment facing the government.

\section{CONCLUDING REMARKS}

There are several similarities in the British and Swedish post-war tax debate. Both countries struggled with what to do with temporary tax measures implemented during the war, as well as with inflation and tax avoidance. Moreover, both SAP and Labour were initially hostile towards consumption taxes and in both countries ideas challenging this orthodoxy started to emerge in the late 1940s and early 1950s. Why did these new ideas prevail in Sweden, while the Labour Party in Britain opted for the SET?

In line with Lindvall (2009), economic experts influenced the instruments used, not the goals. Importantly, while the goals were the same in Britain and Sweden (reducing inequality), and some of the suggested instruments were the same (the VAT), the choices made were different. The reason for this, I argue, is the different political environment facing the Left in Britain vis-à-vis in Sweden. This is likely related to how institutions guide expectations and regulate opposition influence, factors that have been shown to be important for left-wing policy elsewhere (e.g. Andersson 2016; Hicks 2013).

The case supports the contention that the Left is more amenable to certain solutions depending on their strategic situation. This is evident in the British case where Nicholas Kaldor first advocated the VAT, and then, when the VAT was rejected with reference to political risk, suggested a safer alternative (the SET), which was later adopted. In the Swedish case, the political risks were lower and experts such as Gösta Rehn and Rudolf Meidner had greater success in promoting the reintroduction of the oms.

\section{REFERENCES}

Andersson, P. F. (2016): Political Institutions and Taxation by the Left: Britain and Sweden Compared. Working Paper, Department of Political Science, Lund University.

Andersson, P. F. - Brambor, T. (2015): The Government Revenue Dataset.

Andra Kammarens Protokoll (Minutes of the Second Chamber, Sweden), 1959.

Åsbrink, P. - Rehn, G. (1951): Full sysselsättning utan inflation (Full Employment without Inflation). In: Discussion Memo Prepared for Deliberations in the Nordic Cooperation Committee. Stockholm. 
Beramendi, P. - Rueda, D. (2007): Social Democracy Constrained: Indirect Taxation in Industrialized Democracies. British Journal of Political Science, 37(4): 619-641.

Bradley, D. - Huber, E. - Moller, S. - Nielsen, F. - Stephens, J. D. (2003): Distribution and Redistribution in Postindustrial Democracies. World Politics, 55(2): 193-228.

Butler, D. - Butler, G. (2010): British Political Facts. Palgrave Macmillan.

Cabinet papers CAB/129/121. (1965): The Outline Plan. Memorandum by the First Secretary of State and Secretary of State for Economic Affairs. Available online at: http://filestore. nationalarchives.gov.uk/pdfs/small/cab-129-121-c-65-53.pdf

Cameron, D. R. (1978): The Expansion of the Public Economy: A Comparative Analysis. The American Political Science Review, 72(4):1243-1261.

Cusack, T. R. (1997): Partisan Politics and Public Finance: Changes in Public Spending in the Industrialized Democracies, 1955-1989. Public Choice, 91(3-4): 375-395.

Cusack, T. R. - Beramendi, P. (2006): Taxing Work. European Journal of Political Research, 45(1): 43-73.

Dale, I. (2000) (ed.): Labour Party General Election Manifestos 1900-1997. London and New York: Politico's Publishing.

Daunton, M. (2002): Just Taxes - The Politics of Taxation in Britain, 1914-1979. Cambridge, UK: Cambridge University Press.

de Figueiredo, Jr. - Rui, J. P. (2002): Electoral Competition, Political Uncertainty, and Policy Insulation. The American Political Science Review, 96(2): 321-333.

Ellison, N. (2002): Egalitarian Thought and Labour Politics: Retreating Visions. London: Routledge.

Elvander, N. (1972): Svensk skattepolitik 1945-1970 - En studie i partiers och organisationers funktioner (Swedish Tax Policy 1945-1970 - A Study of Parties and Organizations' Functions). Stockholm: Rabén \& Sjögren.

Erlander, T. (1974): Tage Erlander 1949-1954. Stockholm: Tidens förlag.

Erlander, T. (1976): Tage Erlander 1955-1960. Stockholm: Tidens förlag.

Flora, P. - Kraus, F. - Pfenning, W. (1983): State, Economy, and Society in Western Europe 18151975: The Growth of Industrial Societies and Capitalist Economies. Campus Verlag.

Ganghof, S. (2006): Tax Mixes and the Size of the Welfare State: Causal Mechanisms and Policy Implications. Journal of European Social Policy, 16(4): 360-373.

Hadenius, S. (ed.) (2003): Modern svensk politisk historia: Konflikt och samförstånd (Modern Swedish Political History: Conflict and Consensus). (6 th. ed.) Stockholm: Hjalmarson \& Högberg.

Heclo, H. (2010): Modern Social Politics in Britain and Sweden. ECPR Press.

Hibbs, Jr. - Douglas, A. (1977): Political Parties and Macroeconomic Policy. The American Political Science Review, 71(4): 1467-1487.

Hicks, A. M. - Swank, D. H. (1992): Politics, Institutions, and Welfare Spending in Industrialized Democracies, 1960-82. The American Political Science Review, 86(3): 658-674.

Hicks, T. (2013): Partisan Strategy and Path Dependence: The Post-War Emergence of Health Systems in the UK and Sweden. Comparative Politics, 45(2): 207-226.

Imbeau, L. M. - Pétry, F. - Lamari, M. (2001): Left-Right Party Ideology and Government Policies: A Meta-Analysis. European Journal of Political Research, 40(1): 1-29.

Joumard, I. - Pisu, M. - Bloch, D. (2012): Less Income Inequality and More Growth - Are They Compatible? Part 3. In: Income Redistribution via Taxes and Transfers across OECD Countries. Working Papers, No. 926. OECD Economics Department, Paris.

Kaldor, N. (1955): An Expenditure Tax. London: Allen \& Unwin.

Kaldor, N. (1964): Duties as Special Adviser to the Chancellor of the Exchequer. Personal archives of Kaldor Papers. Cambridge: King's College. 
Kaldor, N. (1970): D. E. Lea to Nicholas Kaldor. Personal archives of Kaldor Papers, Cambridge: King's College.

Kato, J. (2003): Regressive Taxation and the Welfare State. New York: Cambridge University Press.

Kittel, B. - Obinger, H. (2003): Political Parties, Institutions, and the Dynamics of Social Expenditure in Times of Austerity. Journal of European Public Policy, 10(1): 20-45.

Konseljakt (1952): Cabinet meeting, 31 March 1952. 1(2).

Konseljakt (1959): Cabinet meeting, 9 October 1959. 4(23).

Lindvall, J. (2009): The Real but Limited Influence of Expert Ideas. World Politics, 61(4): 703-730.

Lynch, P. (2003): The Conservatives and the Wilson Application. In: Daddow, O. J. (ed.): Harold Wilson and European Integration: Britain's Second Application to Join the EEC. Cass series: British Foreign and Colonial Policy. London, Portland, Oregon: Frank Cass Publishers.

Martin, C. J. (2015): Labour Market Coordination and the Evolution of Tax Regimes. Socio-Economic Review, 13(1): 33-54.

Meidner, R. (1946): Farväl till omsättningsskatten (A Farewell to the Turnover Tax). Fackföreningsrörelsen, (50): 573-576.

Nohlen, D. - Philip Stöver, P. (2010) (eds): Elections in Europe: A Data Handbook. Baden-Baden, Germany: Nomos Verlagsgesellschaft.

Parliamentary Minutes Second Chamber (Sweden) (1959): "AK 1959 vol. 24."

Prasad, M. - Deng, Y. (2009): Taxation and the Worlds of Welfare. Socio-Economic Review, (7): 431-457.

PRO T 328/100 (1967): Report of the Chief Secretary's Committee on Value-Added Tax Questions.

Rehn, G. (1946): Gallup om Oms (Gallup about the Turnover Tax). Skogsindustriarbetaren, (2526): $1,10,30$.

Rehn, G. (1948): Ekonomisk politik vid full sysselsättning (Economic Policy at Full Employment). Tiden, 40(3): 135-142.

Rollings, N. (2003): The Confederation of British Industry and European Integration in the 1960s. In: Daddow, O. J. (ed.): Harold Wilson and European Integration: Britain's Second Application to Join the EEC. Cass series: British Foreign and Colonial Policy. London, Portland, Oregon: Frank Cass Publishers.

Steinmo, S. (1993): Taxation and Democracy. New Haven and London: Yale University Press.

Särlvik, B. (1967): Party Politics and Electoral Opinion Formation: A Study of Issues in Swedish Politics 1956-1960. Scandinavian Political Studies, 2:167-202.

Thirlwall, A. P. (1987): Nicholas Kaldor. In: Grand Masters in Economics. Brighton, UK: Wheatsheaf Books Ltd.

Thorpe, A. (2008): A History of the British Labour Party. (Third edition.) Palgrave Macmillan.

Timmons, J. F. (2010): Taxation and Credible Commitment: Left, Right, and Partisan Turnover. Comparative Politics, 42(2): 207-227.

Whiting, R. (2000): The Labour Party and Taxation - Party Identity and Political Purpose in Twentieth-Century Britain. Cambridge, UK: Cambridge University Press.

Wigforss, E. (1954): Minnen III 1932 - 1949. Stockholm: Tidens förlag.

1949 års skatteutredning (The 1949 Committee on Taxation). Den statliga direkta beskattningen (The Direct Taxation of the Central Government). 1951: 51 Stockholm.

1952 års kommitté för indirekta skatter (The 1952 Committee on Indirect Taxation). Den statliga indirekta beskattningen (The Indirect Taxation of the Central Government). 1957:13 Stockholm. 